\title{
SPIRITUALISTAS TAUBAT DAN NESTAPA MANUSIA MODEREN
}

\author{
Eni Zulaiha \\ E-mail: enizulaiha@uinsgd.ac.id
}

\begin{abstract}
ABSTRAK
Kompleksitas kehidupan manusia berawal karena ia bukan sekedar mahluk biologis. kematiannya bukanakhir dari perjalanan hidupnyan namun awal dari kehidupan abadinya. Kebahagiaan manusia bukan hanya pada pemuasaan kebutuhan jasmaninya, tetapi terkait dengan pemenuhan kebutuhan rohaninya. Tetapi kehidupan manusia moderen yang terpaku pada rasionalitas dan standar- standar ilmu yang mengikuti rumus- rumus kaku kaum positivisme telah membuat rumusan kebahagiaan yang hanya bersifat material. Akibatnya manusia tercerabut dari nilai -nilai dan akar-akar spiritualitas yang menjadikan manusia terasing dan nestapa dalam kehidupanya. Spiritualitas dalam kehidupan manusia adalah kekuatan mahadasyat yang dapat menghubungkan manusia dengan segala apa yang dilakukan dan tujuan apa ia melakukannya. Spiritualitas adalah iradah rabbaniyah yang mengalahkan kekuatan lain. Ia bagaikan kekuatan daya listrik dalam pembangkit listrik. Kabel dan lampu hanyalah perantara. Ia mengalir sebagai motor penggerak amal manusia. Ia bersifat bebas dan berdaya kekuatan yang luar biasa. Ia adalah potensi yang baik yang dapat menggerakan manusia terhubung dengan sesuatu yang terdalam pada diri manusia. Nestapa manusia moderen adalah keterpisahan dengannya. Formula penting yang harus ditemukan untuk manusia yang sudah terlanjur terpaku pada rumus-rumus modernitas yang rasional dan materialistik adalah spiritualitas yang dapat mendamaikan rasionalitas dan transendenalitas. Kajian filosofis yang mendalam dalam memelihara keterhubungan manusia dengan tuhannya dengan cara-cara yang lebih subtansial dengan menghidupkan beberapa ajaran tasawuf dalam keseharian kita merupakan tawaran dalam tulisan ini.
\end{abstract}

\section{KATA KUNCI}

Tobat; Nestapa; Spiritual

DOI: https://doi.org/10.15575/saq.v2i2.2976

\section{A. PENDAHULUAN}

Manusia adalah mahluk Allah yang bukan hanya berupa onggokan benda biologis yang dapat membusuk setelah ia meninggal. Tetapi lebih jauh dari itu, selain mahluk biologis, ia merupakan mahluk spiritual. Oleh karena itu kematian bukanlah akhir dari perjalanan hidupnya. Kematian justru awal dari kehidupan abadinya. Kebahagiaan manusia bukan hanya pada pemuasaan kebutuhan jasmaninya, tetapi terkait dengan pemenuhan kebutuhan rohaninya. Itulah kompleksitas kehidupan manusia.
Dalam doktrin agama Islam bersikap adil atau seimbang antara jasmani dan rohani atau antara hal hal yang bersifat profan dan relegius akan mendatangkan kebahagiaan dunia dan akhirat. Pendek kata mustahil rasanya manusia dapat hidup bahagia jika ia hanya berkonsentrasi pada pemenuhan kehidupan jasmani belaka. Namun juga, jika hanya berkonsentrasi pada persoalan ruhani, akhirat dan relegious juga akan membuat manusia menjadi mahluk a sosial yang jelas dikecam oleh al-Qur'an. 

Tuntutan keseimbangan hidup antara dunia dan akhirat agar manusia dapat hidup selamat dunia akherat. Hal ini meniscayakan beberapa praktek keberagamaan yang menuju pada dua hal tersebut. Sementara itu kegagalan abad moderen sempat membuat manusia terasing dari fitrahnya, oleh sebab itu manusia kembali merindukan dan mencari hal-hal yang bersifat spiritual, tetapi spiritualitas dalam bentuk baru, yakni spiritualitas yang dapat mendamaikan rasionalitas dan transendenalitas.

Tulisan ini bermaksud memberikan pemahaman, tentang model menghidupkan spiritualitas sebagai unsur penting mencapai kebahagian manusia di abad rasionalitas dan standar- standar ilmu yang mengikuti rumusrumus kaku kaum positivisme. Tulisan ini juga bermaksud memberikan definisi ulang beberapa maqom dan ahwal yang dikenal dalam tradisi tarekat atau tasawuf yang dipandang kaku dan bermusuhan dengan segala hal yang berbau kehidupan rasional. Adapun metode dalam tulisan ini deskriptif analitis dengan tehnik pencari data book survey dan wawancara tokoh.

\section{B. HASIL DAN PEMBAHASAN}

\section{Nestapa Manusia Moderen}

Erich Fromm menyebut manusia moderen adalah manusia yang mengalami rasa keterpisahan (experience of separateness). Terpisah artinya tidak memiliki kodrat kemanusiaan lagi: kodrat untuk berpikir, kodrat untuk merasa, kodrat untuk melakukan tindakan sesuai kemauan sendiri. terpisah juga berarti ia tidak bisa memahami dunia, orang dan peristiwa secara aktif keterpisahan ini secara tidak disadari menjadi sumber kecemasan, menimbulkan malu dan rasa bersalah ${ }^{1}$

Mereka malu bukan karena aurat mereka terlihat, mereka malu karena tiba-tiba merasa terasing satu sama lain, bersama itu mereka memiliki kerinduan untuk bergabung, melebur menjadi satu. Masih menurut Fromm,

\footnotetext{
1 Erich Fromm, The Art of Loving (New York: Harper and Row, 1989, halman 8-9
}

sepanjang sejarah kehidupan manusia, ia berupaya mengatasi keterpisahan, mencapai kesatuan, mentransendensikan kehidupan individualnya, dan menemukan kesatuan dengan Tuhan (at-onement). Cara terbaik untuk mencapai semua itu adalah cinta, karena dalam cinta manusia menjalankan kodrat kemanusiaannya. Cinta lahir dalam kebebasan, ia tidak lahir dalam paksaan. Salah satu karakteristik cinta adalah saling menghargai. ${ }^{2}$

Tentang mengapa manusia moderen mengalami kenestapaan saat mengalami keterpisahan seperti kata Fromm di atas? Mungkin pendapat Thabatabai $^{3}$ ketika menafsirkan Qs al-Baqoroh ayat 102 (tentang Harut dan Marut) dalam tafsirnya dapat menjawab pertanyaan penulis. Dengan analisa berbagai peristiwa luar biasa (af'al alKhariqoh li al-'Adah). Sebagian besar jika diselidiki secara seksama, ternyata tidak luar biasa, boleh jadi itu timbul karena latihanlatihan intensif seperti berjalan pada seutas tali, atau karena sebab-sebab alamiah yang tersenbunyi dari pengetahuan orang banyak, seperti berjalan dalam api tanpa luka bakar, karena bantuan zat-zat kimia tertentu: atau keterampilan untuk menggerakan sesuatu secara cepat sehingga mata orang sukar menangkap seperti permainan sulap.

Walaupun demikian, ada juga kejadian-kejadian luar biasa yang tidak dapat dijelaskan dengan sebab-sebab fisika yang lazim. Misalnya, meramalkan apa yang terjadi (Ekstra Sensory Perception), pekasih untuk menimbulkan cinta atau pembenci untuk menimbulkan kebencian, hal-hal yang dapat mempengaruhi orang secara gaib (spiritual healing) kejiadian-kejadian itu sudah biasa atau pernah kita alami atau saksikan.

Thabathaba'i menunujuk berbagai sebab: pertama kemampuan itu muncul karena kekuatan dan keyakinan bahwa hal itu akan terjadi pada diri pelakunya (Quwwatul Iradah wa al-Imanu bi al-Ta'tsir), ilmu jika sudah pada tingkat kepastian, alat- alat indra akan melihat itu benar terjadi. Lihat misalnya beberapa orang yang ikut pertemuanpertemuan untuk memotivasi diri dipandu

\footnotetext{
${ }^{2}$ Ibid hlm 17

${ }^{3}$ Thabataba'i, Tafsir al-Mizan, juz 1 hal 239
} 
dengan seorang Coach yang ahli, dengan katakata dan pikiran positif juga beberapa aktifitas imajinasi, peserta bisa sangat terbawa begitu rupa dan mengosongkan pikirannya lalu memasukan kata-kata bijaksana dari sang Coach dan mereka meresa lega, karena merasa sudah menemukan jawaban dari masalahnya. Lihat juga misalnya seorang dokter yang dengan sungguh -sungguh mengatakan pada pasiennya bahwa penyakitnya dapat disembuhkan. Dengan tanpa susah payah pasien itu juga merasa ringan dan pasti sembuh.

Jadi manusia dapat menimbulkan kekuatan yang luar biasa itu bisa dilakukan dengan bersandar pada kekuatan dan kemauannya. Yang jadi persoalan berikutnya, apa jenis "mahluk yang menjadi sumber kekuatan itu?" al-Qur'an menyebutnya ruh, orang orang moderen menyebutnya dengan berbagai nama: mind, soul, spirit, pschye. Selain ruh yang jadi sumber kekuatan kemauan itu adalah ada yang memperolehnya dengan bersekutu dengan setan atau jin. Dan sebagian lain memperoleh pertolongan malaikat.

Menurut Thabataba'i semua kekuatan itu, baik yang bearasal dari ruh, jin atau malaikat bersifat terbatas dan pengaruhnya kondisional sekali. (Mahdudat al-Quwwah muqayyad al-Atsar). Pada sisi yag berbeda, ada beberapa orang, seperti nabi dan kekasih Allah, yang taat pada Allah, yang taat beribadah dan penuh keyakinan kepada Allah. Mereka tidak menghendaki sesuatu kecuali untuk Allah dan karena Allah. Inilah kemauan yang suci, kehendaknya tidak tercemari oleh kecenderungan pribadi. Ia hanya bergantung pada Allah yang Haqq. Inilah kehendak ilahi (iradatu al-rabbaniyah) yang tidak terbatas dan tidak kondisional. Kekuatan yang lahir dari Iradah rabbaniyah mengalahkan segala kekuatan lain.

Dari uraian di atas dapat disimpulkan bahwa spiritualitas dalam kehidupan manusia merupakan sebuah kekuatan yang dapat menghubungkan manusia dengan segala apa yang dilakukannya, dan untuk tujuan apa ia melakukannya. Sumber kekuatan spiritualitas adalah iradah rabbaniyah. Sehingga seperti yang diuraikan di atas bahwa Kekuatan yang lahir dari Iradah rabbaniyah mengalahkan segala kekuatan lain. Iradah rabbaniyah jika diibaratkan pada pada pembangkit listrik ia adalah kekuatan daya listrik itu. Kabel dan lampu hanyalah perantara. Ia mengalir sebagai motor penggerak amal manusia. Ia bersifat bebas dan berdaya kekuatan yang luar biasa. Ia adalah potensi yang baik yang dapat menggerakan manusia terhubung dengan sesuatu yang terdalam dirinya.

Seperti apa yang ditulis oleh Fromm di awal, bahwa nestapa manusia moderen adalah keterpisahannya dengan iradah rabbaniyah. Jika kita setuju dengan ungkapan Fromm diatas, penulis merasa perlu mempertanyakan lebih lanjut, memangnya apa yang ditawarkan kehidupan moderen pada manusia? Apa betul tidak ada manusia yang selamat dari gegap gempitanya kehidupan moderen?

Menurut penulis, kehidupan moderen itu menawarkan tiga hal: harapan, kesempatan dan tantangan. Ia menjanjikan harapan untuk perbaikan nasib dan keberlimpahan materi, membuka peluang luas untuk aktualisasi diri manusia, dengan memacu diri bekerja keras sebagai tantangannya. Kehidupan moderen bukanlah kehidupan yang ringan dijalani, ia kehidupan yang keras, karena ia ajang persaingan yang ketat. Mereka yang berhasil sebagai pemenang akan memperoleh keberlimpahan harta dan prestise yang naik. Sedangkan para pecundangnya akan mengalami frustasi dan kehilangan harga diri. Lalu masihkah ada yang berharga dari kehidupan seperti ini?

Jika jawabannya didasarkan pada pandangan psikologis yang menyatakan bahwa makna hidup berada pada setiap kenyataan yang dihadapi manusia. Manusia adalah mahluk pembuat (ber)cerita, dengan lobus fonta dan sistem lembik yang ada di otaknya manusia bisa menyimpan trauma masa lalu atau bahkan menebak- nebak masa depannya. Maka kebermaknaan hidup manusia itu bergantung pada persepsi yang dibangunnya. Bukankah ada manusia yang tetap bahagia dalam kekurangan harta dalam hidupnya, sementara ada sebagian manusia lain yang menderita dan frustasi karena kekurangan harta dalam hidupnya?. Artinya keberlimpahan dan kekurangan harta bukan ukuran manusia bahagia atau sedih dalam hidupnya.

Jika setuju dengan ungkapan penulis di atas, maka kunci manusia agar tidak 
terjerembab pada kenestapaan yang diakibatkan dari kehidupan moderen adalah sejauhmana kita dapat menyesuaikan diri dari tuntutan modernisasi dan mampu pula menemukan makna dari kehidupan moderen itu sendiri.

Jika kunci sukses manusia dalam kehidupan moderen itu menyesuaikan diri dari tuntutan modernisasi dan mampu pula menemukan makna dari kehidupan moderen itu sendiri. Lalu bagaimanakah cara menyesuaikan diri dari tuntutan modernisasi dan mampu pula menemukan makna dari kehidupan moderen itu sendiri ?.

\section{Membangun Keterhubungan Dengan Allah}

Dalam salah satu uraian dan ungkapan Prof. Dr. Nurshamad Kamba ${ }^{4}$, ia menyatakan: "Pada diri manusia telah ditanamkan ketergantungan dan kerinduan untuk kembali padaNya, namun sisi lain ada hawa nafsu yang mendorong perjalanan sebaliknya (bukan menuju Allah). Kecenderungan hawa nafsu ini diperkuat dan diperindah oleh Syetan ${ }^{5}$. Karenanya, al-Junaid menegaskan bahwa perjalanan menuju Allah membutuhkan jihad yang berkesinambungan. masih menurut Prof. Nurshamad yang mengutip al-Junaidi, bahwa salah satu praktek jihad berkesinambungan itu adalah dengan menjaga niat. Nabi saw bersabda "Sesungguhnya perbuatan ditentukan oleh niatnya.". (ber)Islam adalah suatu perbuatan, karena itu Islam ditentukan oleh niat, bukan saja niat dalam ibadah (seperti yang diajarkan dalam fiqh), melainkan niat untuk hidup itu sendiri.

Jika keberadaan manusia di dunia ini dipandu dengan niat yang suci, Dalam konteks ini adalah niat agar hidupnya selalu terhubung dengan iradah rabbaniyah, dimana jihad berkesinambungan sebagai bagian dari niat itu. Maka, manusia hidup dalam kehidupan moderen atau tidak, bukan masalah yang berarti. Lalu bagaimanakah cara agar manusia

\footnotetext{
${ }^{4}$ Wawancara cdengan prof. Dr Nurshamad Kamba tanggal 7 agustus 2015

${ }^{5}$ QS: .27:4
}

berniat tetap terhubung dengan Allah Yang Maha Absolut?.

Prof Dr. Nurshamad ${ }^{6}$ menjelaskan bahwa menjalin kontak dan komunikasi ini tidak dalam bentuknya yang formalistik seperti melakukan ritual tertentu atau membaca zikir maupun wirid tetapi dalam bentuk esensinya. Esensi hubungan manusia dengan Tuhan terpatri dalam realisasi dua kesadaran azali, yakni (1) Ketergantungan pada Tuhan; dan (2) Kerinduan yang (memaksakan diri) kepada Yang Maha Sempurna.

Bagaimana kita bisa mengimplementasikan ketergantungan pada Tuhan, dan kerinduan pada Nya? Sehingga ketika kita berzikir, shalat, atau melakukan ritual lainnya dapat memenuhi dua esensi hubungan manusia dan Tuhannya?.

Di dalam al-Qur'an disinggung bahwa shalat itu berfungsi untuk mengingat Allah, dan Shalat juga berfungsi sebagai media pelindung manusia dari perbuatan keji. Allah juga berfirman dalam al-Qur'an: Hai orangorang yang beriman, penuhilah seruan Allah dan seruan Rasul apabila Rasul menyeru kamu kepada suatu yang memberi kehidupan kepada kamu, ketahuilah bahwa sesungguhnya Allah membatasi antara manusia dan hatinya dan sesungguhnya kepada-Nyalah kamu akan dikumpulkan (QS. al Anfâl: 24). Artinya shalat adalah media untuk memenuhi kerinduan kita pada Allah ?. Namun, ini tentu bukan perkara mudah, karena Allah juga sudah memberi izin pada Iblis untuk menggoda manusia hingga akhir zaman. Akibatnya ada banyak manusia yang sulit memenuhi seruan Allah, atau kalaupun shalat tidak dapat menjadikan shalatnya sebagai media mengingat Allah dalam arti sesungguhnya. Menurut penulis, jikapun ada orang yang tidak shalat atau shalat tapi tidak memenuhi arti sesungguhnya, itu bukan benar-benar salah setan yang menggoda, namun manusia itu yang memperturutkan kemauan setan.

Ketika manusia hendak dilahirkan, alQur'an menyebutkan bahwa ia telah diambil sumpahnya, semata agar ia ingat tempatnya

\footnotetext{
${ }^{6}$ Wawancara dengan Prof. Dr Nurshamad Kamba, Tanggal 23 agustus 2015
} 
kembali dan tidak melupakan Allah. Jika diumpamakan saat itu ibaratnya Allah tengah menyisipakan dalam hatinya sebuah mesin penghubung atau sinyal bahwa anatara manusia dan Allah terhubung. Tinggal seberapa intens keep kontaks dengan sinyal itu, Maka semakin mudah ia melepas rindu pada Tuhannya, dan senantiasa mudah menemukan arah untuk kembali pada-Nya. Begitu pula sebaliknya, semakin dia tidak menggunakan mesin penghubung itu, maka semakin lemah sinyal dan sulit berkomunikasi dengan Tuhannya, hingga setan lah yang dipilihnya untuk menemani hidupnya hingga Tuhan memanggil ia kembali.

Mesin itu adalah ruh, Allah memberi bekal kepada manusia dengan "tiupan Ruh dari-Nya" yang akan memberikan potensi besar bagi manusia untuk melakasanakan tugas kekhalifahan dari Tuhanya. Karena ketika manusia menjadi khalifah tidak bisa jika hanya mengandalkan pada kekuatan jasmaniah fisiknya. Namun, ia juga harus mengaktifkan Roh-Nya. Pada roh manusia ini ditanamkan "kesadaran akan ketergantungan pada Allah dan kerinduan pada-Nya. Dalam pemaparan prof. Nurshamad menyebutkan bahwa, menurut al Junaid, Allah memberikan memberikan dukungan kepada manusia, dengan dua cara yakni: (1) dengan cara pewahyuan melalui Nabi/Rasul; dan (2) dengan membisikkan kebaikan dalam jiwa. Jadi, merawat ketergantungan dan kerinduan pada Allah bagi manusia, sejatinya bukan sesuatu yang sulit. Karena Allah sudah menyiapkan perangkat lunak berupa ruh yang selalu mengajak manusia mengingat Allah dan merindukan masa-masa indah kebersamaan antara manusia dan Allah. Jika meminjam istilah Rumi, jika kita seruling bambu, maka seruling itu selalu rindu pada kondisi saat ia masih menjadi bambu dan merindukan saat berkumpul dengan rumpunan pohon bambu lainnya. Karena rindu, maka para sufi mencintai

${ }^{7}$ Harun Nasution, Falsafah dan Mistisisme dalam Islam, Bulan Bintang, Jakarta, 1973 hal 34

${ }^{8}$ Al-kalabazi merinci maqomat pada taubat, zuhud, sabar, kefakiran, kerendah hatian, takwa,tawakal,kerelaan, cinta dan ma'rifah. Sedangkan
Allah, dan karena cinta Allah (mahabbah) maka sang sufi merefleksikan sifat-sifat Allah (at-Takhalluq bi akhlâqillâh) dalam setiap aktifitasnya di muka bumi ini.

Kaum sufi mewujudkan sifat Allah dalam kehidupannya. Misalnya: Allah yang Yang Maha Mencipta dan Maha Memberi namun tanpa pamrih. Maha Bijaksana dan Maha Perkasa namun tulus se-tulus-tulusnya. Pendeknya sang sufi, menghidupkan (living) cinta Allah itu dengan menurunkannya pada perbuatan baik yang dianggap dapat merefleksikan bahkan mempersonifikasikan sifat sifat yang indah dari Allah. Mereka benar- benar berusaha menjdi wakil tuhan di dunia (khalifatullah fi al- ardi).

Oleh karena dibutuhkan niat yang suci dan jihad yang berkesinambungan agar manusia senantiasa berada dalam rindu dan cinta pada Allah. Dan salah satu praktek jihad berkesinambungan itu adalah dengan menjaga niat yang suci bahwa ia ingin hidup dengan benar (senantiasa terhubung dengan Rabbnya). Jatuh- bangun manusia berjihad dan segala pengorbanan dan perjuangan itu menjadi nyanyian rindu seperti yang dipraktekan para hamba sejati, demi mencapai niat suci hidupnya yang esensinya adalah kembali pada Allah. Situasi tarik-menarik antara menuju kebaikan dan menuju ketidakbaikan ini terusmenerus terjadi, karena itu jihad dilasungkan secara terus-menerus pula. Jihad yang dimaksud adalah jihad melawan kecenderungan buruk dan berjuang mengikuti "seruan kebaikan".

\section{Membangun Keterhubungan Dengan Maqomat}

Maqomat adalah jalan pendekatan diri, intinya penyucian $\operatorname{diri}^{7}$. Ulama berbeda pendapat tentang maqamat itu $^{8}$, di atas maqomat itu ada cinta, ma'rifah, fana dan baqa dan ittihad kemudian mengambil bentuk al-hulul atau wihdat al-wujud. Dalam tasawuf

al-Ghazali merincinya menjadi: taubat, sabar , kefakiran, zuhud, tawakal, cinta, ma'rifah dan ridha. Sedangkan al-Qusyairi merincinya: taubat, wira'i. Zuhud, tawakl, sabar dan ridha 
memang terdapat beberapa latihan pendakian spiritual melalui praktek zuhud, tawakkal, sabar, rida dsb, tetapi semuanya ini terkait dengan taubat. Seseorang dapat melakukan praktek zuhud, tawakkal, sabar, ridla ketika ia mencapai puncak kesadaran taubatnya; kemudian ketika ia merealisasikan praktek zuhud ia pun melakukan taubah secara berkesinambungan. Jadi taubat hendaknya mejadi tangga awal sekaligus menjadi "ruh" dan tangga ahir perjalanan manusia ketika ingin terus terhubung dengan $R a b b$ nya (eling atau ma'rifatullah).

Keterangan dari Prof. Nurshamad ${ }^{9}$ tentang pandangan Imam Junaid, akan memperjelas hal di atas. Bahwa: "perjalanan menuju Allah" tiada lain adalah menempuh maqamat. Ia menjelaskan bahwa hakekat maqam adalah posisi yang didapatkan hamba ketika berhadapan dengan Tuhan. Maqamat bukan tahapan-tahapan pendidikan yang dapat dipahami secara linier atau teknik berjenjang. Maqamat harus dipahami sebagai "siklus dalam proses pendakian spiritual" atau taqarrub. Posisi maqamat melibatkan kesadaran tentang dua hal di atas (ketergantungan dan kerinduan kepada Allah).

Dalam literatur sufi dikenal juga istilah ahwal, yakni keadaan mental yang diberikan kepada seseorang, seperti persaan senang, sedih, takut dan sebagainya ${ }^{10}$. Ahwal jelas berbeda dengan maqomat, ahwal bersifat sementara, datang dan pergi ke diri seorang sufi dalam perjalanan mencari Tuhan ${ }^{11}$.

Seperti yang ditegaskan Prof. Dr Nurshamad, ${ }^{12}$ bahwa Al-Junaid mewasiatkan dalam Teori tentang maqaqmat dan ahwal bahwa al-taubah lil khawas sudah mencakup keseluruhan maqam lainnya. Karena taubat merupakan aktivitas yang dilakukan dalam seluruh perjalanan pendakian spiritual.

Pada umumnya, taubat dipahami sebagai kegiatan penyesalan dan permohonan

\footnotetext{
${ }^{9}$ Wawancara dengan Prof, DR. Nurshamad Kamba, tanggal 3 september 2015

${ }^{10}$ Al-Qusyairi, 1972,

${ }^{11}$ Amin Syukur, Menggugat Tasawuf sufisme dan tanggung jawab Sosial abad 20, Pustaka Pelajar, Jogjakarta,1999, hal 50

${ }^{12}$ Wawancara dengan Prof. Dr Nurshamad kamba tanggal 10 september 2015
}

maaf atau permohonan ampun kepada Allah. Dalam dunia tarekat, Taubat adalah tempat awal pendakian bagi para salik dan maqom pertama bagi sufi pemula. Hakikat taubat menurut bahasa adalah kembali, artinya kembali dari sesuatu yang dicela menurut syara' menuju sesuatu yang terpuji menurut syara'. Menurut Ahli Sunnah mengatakan bahwa syarat diterimanya taubat ada tiga, yaitu: menyesali atas perbuatannya yang salah, menghentikan perbuatan dosanya, dan berketetapan hati untuk tidak mengulanginya

Menurut Imam Junaid pengertian taubat seperti itu masih bersifat awam, belum yang dimaksudkan sebagai esensi atau hakikatnya. Taubat bukan sekedar istigfar. Membaca istigfar ribuan kali kalau hanya sekedar membaca tetap tidak menyentuh esensi taubat, apalagi kalau hanya dikaitkan dengan permohonan ampunan atas dosadosa. ${ }^{13}$

Taubat dalam tradisi sufi, dibangun atas paradigma tentang Tuhan yang berbeda dengan para mutakallimin atau hingga abad sekarang ini $^{14}$ Tuhan memang dilukiskan dalam al-Qur'an dengan dua model, yang pertama Ia berada dalam jarang yang jauh ini terutama bagi orang kafir yang hatinya tumpul, ${ }^{15}$ namun Tuhan juga berada dalam jarak yang amat dekat ${ }^{16}$. Jauh dekatnya Tuhan itu tergantung pada suasana hati seseorang, maka yang perlu dilakukan adalah menggerakan hati nurani agar beriman dengan hati yang bening (qolbun salim) dan hati inilah yang dijadikan modal dasar membangun sekaligus menjaga keterhubungan manusia dengan Rabb-nya.

Tuhan dalam kajian tasawuf menempati posisi yang sentral, karena esensi ajaran tasawuf adalah mendekatkan diri pada allah sedekat-dekatnya, sehingga manusia bisa mengetahui Allah (ada sebagian yang mengartikan melihat Allah) dengan mata

\footnotetext{
13. Abu al Wafa al Ganimi Al-Taftajani, Madkal ila al-tashawuf al-Islami, Darul al-Tsaqofah, Kairo, 1979 hlm 237 .

14 Budhy Munawar-Rahman, New age dalam Rekonstruksi dan Renungan Relegius Islam , Paramadina, Jakarta, 1996 hal 49

${ }^{15}$ QS Fusshilat ayat 44

${ }^{16}$ QS Qaf ayat 16
} 
hatinya, bahkan ruhnya dapat bersatu dengan Allah. lebih jauh lagi Budhy MunawarRahman menjelaskan bahwa Tuhan dalam kajian tasawuf itu bersifat ruhani, maka bagian yang dapat mendekatkan diri kepada Tuhan adalah ruh, bukan jasadnya. Selain itu, Tuhan itu maha Suci, maka yang dapat mendekati Tuhan adalah ruh yang suci ${ }^{17}$.

Proses taqorrub ilallah pada awalnya masih dipengaruhi oleh rasa takut akan dosadosa yang dilakukannya. Rasa takut itu kemudian berubah menjadi rasa was-was, apakah taubatnya diterima Allah atau tidak. Seiring dengan itu ada perasaan apakah taubatnya diterima atau tidak. Perasaan ini lah yang disebut ahwal, dan dengan alasan ini pula maka taubat harus terus ada atau dilakukan bersamaan dengan maqomat. Karena taubat merupakan aktivitas yang dilakukan dalam seluruh perjalanan pendakian spiritual dan seperti yang diungkap di awal bahwa dalam Teori tentang maqaqmat dan ahwal bahwa al-taubah lil khawas sudah mencakup keseluruhan maqam lainnya.

Perasaan takut dan hawatir itu lambat laun akan hilang, dan seorang salik akan merasakan adanya kedekatan dengan Allah, lalu berganti dengan rindu dan cinta kepada khaliqnya. Maqomat yang ia lakukan dan beberapa ahwal yang ia rasakan bagaikan nyanyian rindu sebatang bambu yang sudah menjadi seruling akan berkumpul dengan rumpun bambu asalnya pada awal ia diciptakan. Demikian Rumi mengibaratkanya. (alastu bi rabbikum? Qolu bala syahidna ...)

\section{Spirit dalam Taubat}

Ada hal yang berbeda antara pemikiran al-Junaidi dengan tokoh lainnya pada persoalan maqom terpenting, yang menjadi spirit pada maqom- maqom lainnya. Zuhud dimata al-Kalabadzi, al- Thusi dan al-Gazali adalah maqom terpenting dalam proses taqorrub ilallah. Sedangkan dalam pandangan al-Junaidi, spirit taubatlah yang harus ada pada setiap maqomat yang akan dilalui oleh seorang

\footnotetext{
${ }^{17}$ Opcit, Budhy Munawar-Rahman, hlm 96.

18 Abdul Qodir, Muhammad Teladanku,M izania,
} hlm 29 calon sufi. Taubat merupakan aktivitas yang dilakukan dalam seluruh perjalanan pendakian spiritual para salik.

Pandangan penting pada maqam zuhud, nampaknya adanya pandangan yang dikotomis antara dunia dan tuhan. Dunia oleh sebagian ulama sufi dipandang sebagai hijab manusia menuju Allah. Dunia dan Tuhan tidak bisa berada dalam satu kalbu pada saat yang bersamaan. Sementara itu, al-Junaidi memiliki tesis yang berbeda. Ia justru menempatkan taubat sebagai spirit yang harus terus dihidupakan pada saat manusia menjalani maqomat sebagai jalan membangun kedekatan dengan Allah. maka pertanyaan berikutnya, alJunaid tidak memiliki pandangan yang memisahkan antara dunia dengan akhirat. Semacam pandangan yang mirip dengan pandangan kaum pasca moderen yang membuat sekat antara dunia dan akhirat. Bagi al-Junaid akherat dan dunia itu terhubung. Untuk bisa mendekati Allah tidak perlu meninggalkan hal-hal yang bersifat duniawi. Taubat dalam pemikiran tasawufnya al-Junaid menempati posisi yang penting, karena taubat pada pemikirannya memiliki distingsi yang kuat dengan taubat di pemikiran sufi lainnya. " ada apa dengan taubat? " bisakah kita mencapai rindu dan cinta pada Allah cukup dengan taubat? "“

Seperti yang telah disinggung di atas, bahwa taubat bukan sekedar istigfar. Membaca istigfar ribuan kali kalau hanya sekedar membaca tetap tidak menyentuh esensi taubat, apalagi kalau hanya dikaitkan dengan permohonan ampunan atas dosa-dosa.

Jika merujuk pada praktek kehidupan spiritual Muhammad Rasulullah, akan didapati berbagai informasi bahwa meski ia seorang nabi yang sudah pasti diampuni dosanya, ${ }^{18}$ namun Rasulullah menghabiskan malamnya untuk berdzikur dan bersujud pada Allah hingga lututnya bengkak, beristigfar sepanjang malam $^{19}$, berhalwat dan shaum, sehingga Aisyah istrinya pernah bertanya "bukankah engkau seorang rasul, yang pasti diampuni dosanya dan masuk surga, tapi mengapa engkau selalu menyibukkan dirimu dengan

\footnotetext{
19 Abdul Mun'im Muhammad Umar, Khadijah The Ttrue Love Story of Muhammad, 210, hlm 21
} 
shalat, sahum, dan dzikir ?, mari datang ke pelukanku, ini pasti membuatmu lebih nyaman" demikian godaan genit Aisyah pada suaminya, Rasul menjawabnya: " pelukanmu pasti membuat aku nyaman, namun cinta dan rinduku pada Allah lebih memaksaku mendekati Nya". Sambil dielus kepala istrinya itu.

Kisah tadi menurut penulis, memberikan kesan dalam dan menghunjam. Betapa Rasulullah senantiasa memelihara keterhubungan dengan Rabb-Nya. Ritual Rasulullah itu sesungguhnya perjalanan maqomatnya. Ribuan istigfar dan sujudnya adalah indikator pendakian perjalanan spiritualnya $^{20}$. Istighfar seorang Rasulullah tentunya sudah menyentuh esnsi taubat yang sejati. Pengejawantahan dari esensi lâ hawla wa lâ quwwata illâ billâh. Lafadz ini mengandung dua makna yang esensi: [1] hanya dengan Allah suatu upaya terlaksana; [2] manakala suatu upaya terlaksana itu berarti atas Kuasa Allah. Jadi esensi taubat adalah pada pemaknaan dan pelaksana dua hal di atas.

Spirit taubat yang diajarkan Rasulullah ada pada dua hal di atas, maka dapat dipahami jika seseorang hanya dapat melakukan praktek zuhud, tawakkal, sabar, ridla ketika ia mencapai puncak kesadaran taubatnya; kemudian ketika ia merealisasikan praktek zuhud ia pun melakukan taubah secara berkesinambungan. Setiap salik yang berhasil merealisasikan esensi taubah maka secara otomatis memiliki sifat-sifat zuhud, tawakkal, shabr, ridIo dan berbagai maqâmât di sisi Allah. Karena zuhud memerlukan esensi taubah bukan hanya sebagai pengantar menuju zuhud melainkan juga karena dalam zuhud ada taubah. Begitu pula seluruh maqâmât ${ }^{21}$ lainya di samping taubah menjadi pengantar misalnya, menuju tawakkal juga dalam tawakkal ada taubah. Menjadi pengantar menuju ridlo sekaligus dalam ridlo ini juga ada

\footnotetext{
20 Disarikan dari perkuliahan dengan prof Nurshamad Kamba

${ }^{21}$ Maqam (posisi hamba di Hadapan Allah) terkait dengan kesadaran jiwa dan tidak ada hubungannya dengan fisik. Bagaimana mungkin berhadapan dengan Allah secara fisik sedangkan Allah immateril. "Jika kau hanya sekedar menghadap baitullah maka kau menyembah batu"kata al Ghazali. Esensi kiblat adalah
}

taubah dst. Maka hakekat tasawuf adalah maqâmât dan hakekat maqâmât adalah taubah. Dalam hal ini Al-Junaid menegaskan "seseorang tidak akan sampai kepada makrifat sebelum melampaui maqâmât dan ahwâl". ${ }^{22}$ Jadi, taubat menjadi "awal" dari seluruh proses sekaligus "menyertai" seluruh perjalanan seorang salik.

\section{Indikator Keterhubungan Sesorang dengan Allah}

Sesuatu yang menarik pernah penulis dengar dari kuliah Spritualisme and Relegious experience bersama Prof. Nurshamad Kamba ${ }^{23}$ bahwa: pertama, tasawuf bukan ilmu, bukan teori, bukan pula wacana melainkan "hidup dalam hubungan yang intim dan continue dengan Allah SWT". Atas keintiman tersebut manusia mengalami transformasi moral dan perilaku "dari tidak baik menjadi baik", lalu "dari baik menjadi terbaik". Kedua, Tasawuf bukanlah buku yang dibaca, bukan teori dan rumus-rumus yang diterapkan, bukan pula aliran pemikiran yang dapat diidentifikasi melainkan saripati hidup hamba secara totalitas dalam interaksinya dengan Tuhan. Ketiga tasawuf bukanlah hal baru dalam peradaban Islam, melainkan sudah ada dan menjadi dasar ajaran Islam sejak Zaman Nabi. Keempat, pribadi utuh yang menjadi tujuan tasawuf adalah manusia sempurna seperti yang digambarkan dalam al-Qur'an dan sunnah sebagaimana pula yang dicontohkan Rasul Terpilih, Muhammad SAW. Kelima Tasawuf, sejatinya, bukan sekedar ilmu, bukan aliran pemikiran, bukan pula wacana atau teori-teori apalagi golongan-golongan. Melainkan, tasawuf adalah "perjalanan menuju Allah". Mempelajari tasawuf tidak serta-merta menjadikan seseorang bertasawuf. Bahkan,

menghadap kepada Allah yang tiada bertempat tinggal. Al Gazali, ihya 'Ulum al din, jilid 3, hal 176.

${ }^{22}$ Abul a'la al-Afifi dalam Muqoddimah buku ibn arabi "Fusus al-Hikam"

23 Bandingkan dengan Zainal Abidin, Filsafat Manusia: Memahami manusia melalui Filsafat (Bandung, Remaja Rosdakarya, 2006) hl 5 
bergabung dalam paguyuban tarekat tidak serta-merta membuat seseorang menjadi $\mathrm{Sufi}^{24}$

Jika, Tasawuf berarti lima hal di atas,. Lalu apa indikator bahwa sesorang itu sudah menjalani hidup secara totalitas dalam interaksinya dengan Tuhan?, apa indikatornya sesorang sudah memiliki pribadi utuh?, dan juga apa indikatornya sesorang sudah dalam "perjalanan menuju Allah"?. Pertanyaanpertanyaan ini sengaja penulis tulis dengan gaya berpikir penganut faham kausalitas. Namun, sesungguhnya hanya ingin mengantar pembaca pada pemahaman yang lebih dalam dari makna keterhubungan itu.

Seperti yang sudah diungkapakan di awal, bahwa maqomat adalah media muraqobah seorang hamba dengan Allah. Posisi maqamat melibatkan kesadaran tentang ketergantungan dan kerinduan kepada Allah. Maka, indikator sesorang itu sudah dalam "perjalanan menuju Tuhannya" atau belum adalah seberapa sering ia menghadirkan pada dirinyanya perasaan yang membuatnya bertanya "apakah dirinya sudah (senantiasa) berada pada posisi yang membuat Allah restu padanya?."

Jika jawaban dari pertanyaan di atas adalah tidak, langkah yang harus diambilnya (jika ia ingin terus berada pada perjalanan menuju Tuhanya), ia harus berani melakukan koreksi total terhadap hal-hal yang tidak layak bagi seseorang yang direstui Allah, istilah yang biasa dikenal dalam dunia sufi pada fase ini adalah muhasabah. Sudah barang tentu setiap murâqabah menghasilkan kesadaran untuk kembali kepada Allah. Dengan demikian maka murâqabah adalah pendahuluan taubah dan muhâsabah adalah hasilnya.

Manakala seseorang mampu menjaga komitmen taubahnya, yakni memelihara kesadaran akan ketergantungannya kepada Allah, bahkan malah merindukan Allah karena sentuhan keindahan yang disebakan oleh ajakan Allah maka seseorang itu telah memasuki perjalanan maqâmât dalam perjalanan menuju Allah. Artinya, ia sedang menempuh suatu tarekat atau tharîqah yang akan mengantarnya kepada Allah dimana ia akan memperoleh maqâm musyâhadah.
Sebuah maqam yang membuat sesorang dapat melihat dan menyaksikan betapa segala sesuatu terjadi atas 'aktifitas' Allah jua.

\section{PENUTUP}

Ternyata kebutuhan manusia pada spiritualitas tidak bisa diganti dengan tehnologi. Spiritualitas kembali dicari manusia moderen sebagai kebutuhan penting dalam hidup ini. Biasanya kebutuhan terhadap spiritualitas didapat manusia dengan mengikuti beberapa kelompok tarekat atau kelompok kelompok kegamaan tertentu. Namun memenuhi kebutuhan spiritualitas juga dapat dilakukan dengan menghidupkan beberapa ajaran tasawuf dalam keseharian kita.

Wallahu a'lam bi alshawab

\section{DAFTAR PUSTAKA}

Erich Fromm, The Art of Loving (New York: Harper and Row, 1989

Thabataba'i, Tafsir al-Mizan, juz , (Beirut, Daar el Fikr ), 1974

Harun Nasution, Falsafah dan Mistisisme dalam Islam, Bulan Bintang, Jakarta, 1973

Amin Syukur, Menggugat tasawuf sufisme dan tanggung jawab Sosial abad 20, Pustaka Pelajar, Jogjakarta

Abu al Wafa al Ganimi Al-Taftajani, Madkal ila al-tashawuf al-Islami, Darul alTsaqofah, Kairo, 1979

Budhy Munawar-Rahman, New age dalam Rekonstruksi dan Renungan Relegius Islam, Paramadina, Jakarta, 1996

Abdul Qodir, Muhammad Teladanku,Mizania, Bandung, 2008

Abdul Mun'im Muhammad Umar, Khadijah, The Ttrue Love Story of Muhammad,

Abul a'la al-Afifi dalam Muqiddimah buku ibn arabi "Fusus al-Hikam"

Zainal Abidin, Filsafat Manusia: Memahami manusia melalui Filsafat (Bandung, Remaja Rosdakarya, 2006)

\footnotetext{
${ }^{24}$ Wawancara dengan Nurshamad Kamba tanggal 10 september 2015
} 